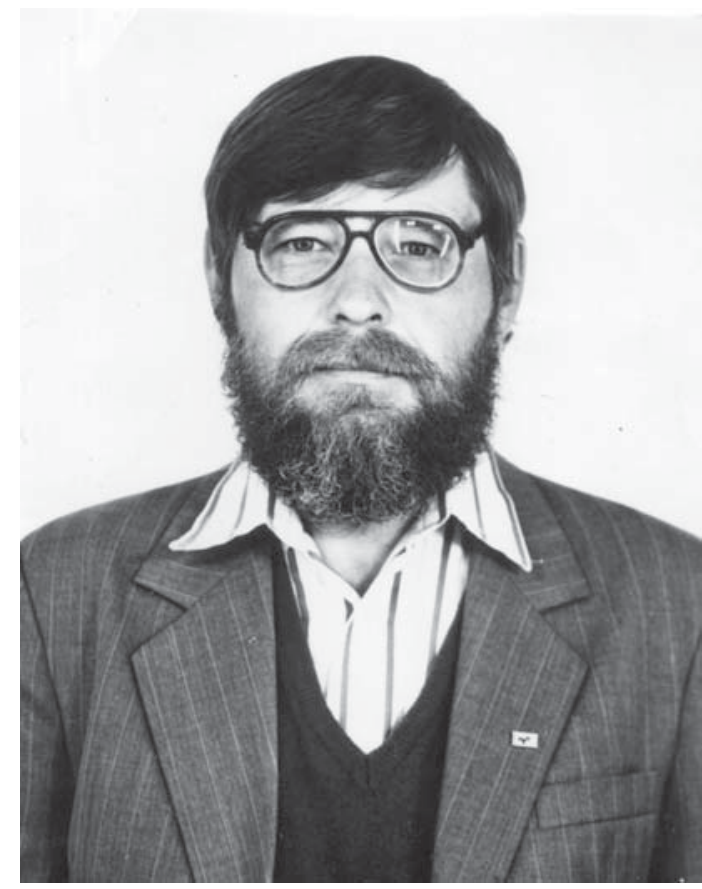

\title{
Vladimir Ivanovich Biserov 13.08.1951 - 31.10.1998
}

In Russian zoology this person is known as the first and for a long time the only specialist in Tardigrada - a very peculiar and hitherto enigmatic group of aquatic microscopic multicellular animals. His fascination with zoology began not even at the university, but much earlier. Vladimir was always interested in small groups: Onychophora, Pentastomida, Kinorhyncha. Don't touch it, it's a silverfish! (Lepisma saccharina), shouted he in delight, it's very ancient!... But tardigrades captivated his imagination the most. Tardigrada are of special interest for taxonomists; no wonder they are so popular among amateur microscopists from the XIX century.

Born into a godforsaken Ural's outback (Shlyashor, Udmurtia), Vladimir Biserov graduated from high school in Glazov, Udmurtia. Then immediately enrolled at the University of Leningrad, Biology Faculty. However, he never graduated (as he put it afterwards, Circum- stances have contributed to...) English on the lower level by the University standards, no place to live... He rented a basement in the Museum Hermitage and was a guest of Roy Medvedev $^{1}$, spent nights in hostels... Got sick, almost lost his arm, and had to take a leave of absence - one year Vladimir worked at a furniture factory in the town Glazov. After recovery he was transferred to the Department of Botany, LSU! After studying for some time he quit, and worked as a dairy loader; then moved to Kazan State University.

Perhaps it was a relatively calm and productive period in his life, although sometimes his fate hung in the balance. Head of the Department of Invertebrate Zoology at the time was a former boatswain and a sea bass, Professor Vladimir L. Vagin. Very much experienced in life himself, he apparently found something in

${ }^{1}$ Soviet and Russian historian, political activist, a leftwing dissident in the USSR. 
a massive, strong, silent, bearded student, who came to him one day and said he will study tardigrades. We cannot say this topic was popular within the department. Vagin himself engaged in parasitic crustaceans. Professor N.A. Livanov, known for his research in evolution of celoma, worked with worms. Professor N.A. Porfir'eva studied turbellarians. Young at the time, perspective docents Anatoly Golubev and Boris Barabanschikhov developed new directions in the ultrastructure of nerve tissue and genetics. Traditionally, many students were sent to carry out graduate work to Kaliningrad and Vladivostok, to work with marine molluscs and other groups of invertebrates. Nobody knew Tardigrada, not only in the department, but in the Soviet Union at large. Well, the professor said, you can work on your chosen subject, but we do not have specialists, so you'll have to study them independently... On the diploma thesis presentation, when the floor was yielded to the supervisor, Professor Vagin said, The student worked singly, even too much on his own, but the work is excellent. This is the first study of the fauna of tardigrades, made in our country with the definition of species. By that time, Vladimir Biserov had excellent command of English, studied Italian, Polish and SerboCroat, translated scientific literature from many European languages...

In 1978, Prof Vagin recommended his graduate student, who had already done his first work on tardigrada, to his personal acquaintant F.D. Mordukhai-Boltovskoy, head of the Laboratory in the Institute for Biology of Inland Waters RAS, Borok, Yaroslavl disrict. Apparently, Biserov met Mordukhai-Boltovskoy in his first visit to Borok, but when the letter of recommendation arrived, Mordukhai-Boltovskoy was in a hospital, which he never left.

Still, Prof Vagin's recommendation has not disappeared. Six months later Biserov receives an invitation from Dr Yakovlev, a new head of the laboratory. In March 1979, Vladimir Biserov arrives in Borok and stays at the Institute as an assistant researcher. In the beginning, Vladimir together with Vsevolod I. Mitropolskiy. He organizes numerous expeditions to the
Rybinsk and then Gorky reservoirs (more than 30 expeditions from 1979 to 1989). Analysis of samples, qualitative and quantitative analysis, all time-consuming - first years in Borok his study of tardigrades was abandoned. But they stay at the center of his attention, and he continues to perform research on them on top of his routine work.

Vladimir Biserov, as investigator of Tardigrada, had no supervisors or predecessors in Russia. Methods for collecting and processing material and taxonomy of tardigrades he created himself. Starting from the early 1980s he published, each year more and more, mainly on the fauna and taxonomy of freshwater and terrestrial tardigrades of Russia. In 1989, Biserov defended his Kandidadskaya dissertation(Ph.D.) The Fauna of Tardigrades in European Part of Russia in Zoological Institute of the RAS, and immediately received an offer from Academician Skorlato to publish a handbook of tardigrades and write a new volume in the series Fauna of USSR, dedicated to Tardigrada.

Publications and research of V.I. Biserov from the outset attracted attention of his foreign colleagues. It so happened that the main school of Tardigrada in the world became Italian, founded by Lazzaro Spallanzani and Giuseppe Ramazzotti. Shortly after his thesis defending Vladimir received an invitation from Professor Roberto Bertolani to conduct a joint study of some groups of Tardigrada at the University of Modena - the birthplace of the tardigrada research. It was at this university where Italian zoologist Spallanzani in 1777 first named these animals Tardigrada, which means "slow walker”. In 1992, Biserov went to Italy. He quickly became a "full member" of the international scientific community. His ability to speak Italian and English helped him a lot. He was in scientific correspondence with many, if not all of the leading tardigrada researchers in the world, constantly exchanging ideas and samples.

In searching tardigrades V.I. Biserov traveled all over the territory of the Soviet Union: Kola Peninsula, Novaya Zemlya, Naryan-Mar, Dixon, Yamalo-Nenets Autonomous Area, Taimyr, Middle and Southern Urals, Sakhalin, 


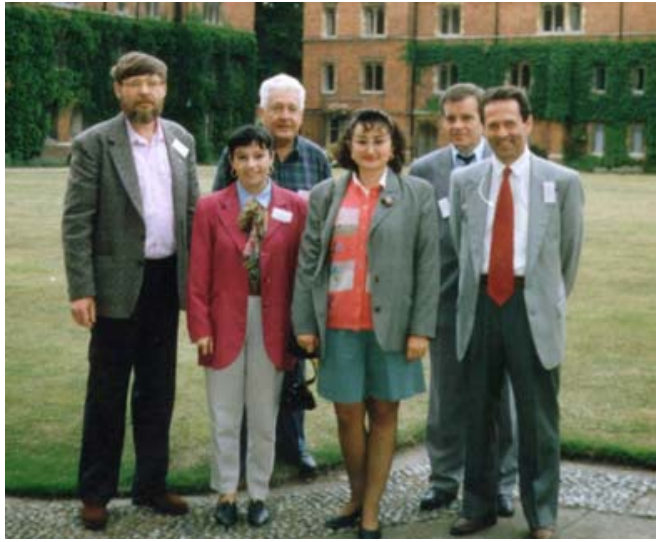

Participants of the $6^{\text {th }}$ International Symposium on Tardigrada, Cambridge, GB, 1994. V. Biserov (to the left), W. Maucci, H. Dastych, A.Guidi, L. Rebecchi, R. Bertolani.

Участники 6-го Международного Симпозиума по Тардиградам, Кембридж, Великобритания, 1994 г. В. Бисеров (слева), В. Мауччи, И. Дастих, А. Гуиди, Л. Ребекки, Р. Бертолани.

Iturup, Far East region, Lake Baikal, the Crimea, North Caucasus, Dagestan, the Baltic States, and, of course, Central Russia. Every summer Vladimir went for a new journey, consistently implementing his program to complete the faunal survey of the country. A considerable amount of samples he received from other scientists, who asked for identification of tardigrades from the Commander Islands, Turkmenistan, United States, Germany, Seychelles, Japan... Perhaps (anyway he had premises for that), having excellent memory for all kinds of the world fauna and enviable capacity for work, V.I. Biserov could become an international expert in Tardigrada. He was both director and performer of such projects as The Study of Tardigrada Fauna of Russia, Zoogeographical Analysis of the World Fauna of Tardigrada, The Fauna and Systematics of Tardigrades of Lake Baikal, supported by RFBR; worked in the International program Biodiversity. His research was repeatedly supported by the International Science Foundation (ISF) and other organizations in this country and abroad.
Before Biserov started his research, Russia and the USSR in terms of tardigradology was a giant white spot. In essence, V.I. Biserov was primarily a fauna scholar and a taxonomist. Excellent knowledge of the Code of Zoological Nomenclature, extraordinary care and sensitivity when describing new species, granted him sincere respect of his colleagues. At international symposia his faunal research surprised with granularity. The first in his life, his talk at the international tardigrada symposium in 1994 in Cambridge dedicated to the study of Taimyr tardigrades, ended with applause. V.I. Biserov discovered and described 39 new species of tardigrades, set three new genera: Eremobiotus Biserov, 1992, Pseudohexapodibius Bertolani \& Biserov, 1996, Xerobiotus Bertolani \& Biserov, 1996. His immediate next task was to publish a monograph on Tardigrada of Russia and adjacent territories. Now, alas, such a work is unlikely to be completed in the foreseeable future. But details of his research are used in a number of books, including The Biology of Tardigrades by I.M. Kinchin, 1994.

Vladimir had a very attractive personality. He was quiet and taciturn, friendly and reliable. His solid, strong nature was complimented by powerful analytical and impartial thinking of a scientist, sincere empathy and truly Yesenian breadth of soul. He was an open and candid man, calm in communication; conversations with him were colored with his charming gentle humor. Enthusiasm of V.I. Biserov commanded respect even among people remote from science, and attracted amateurs from all over this vast country. For instance, he took time for a long correspondence with a person from Kotlas, Kirovskaya obl, who, inspired by Vladimir's article, wrote to him, got a microscope and began studying tardigrades. People of different professions sent samples to him, and when they learned that Biserov dedicated his vacation to sample collection, always invited him. Once he was in Nogliki, in northern Sakhalin, with a person he accidentally met in Leningrad. In Makhachkala, they took him for a local guy, and in Italy for native Italian!

Writer and traveller Vasily Golovanov, who wrote a lot about nature and its scholars, met 


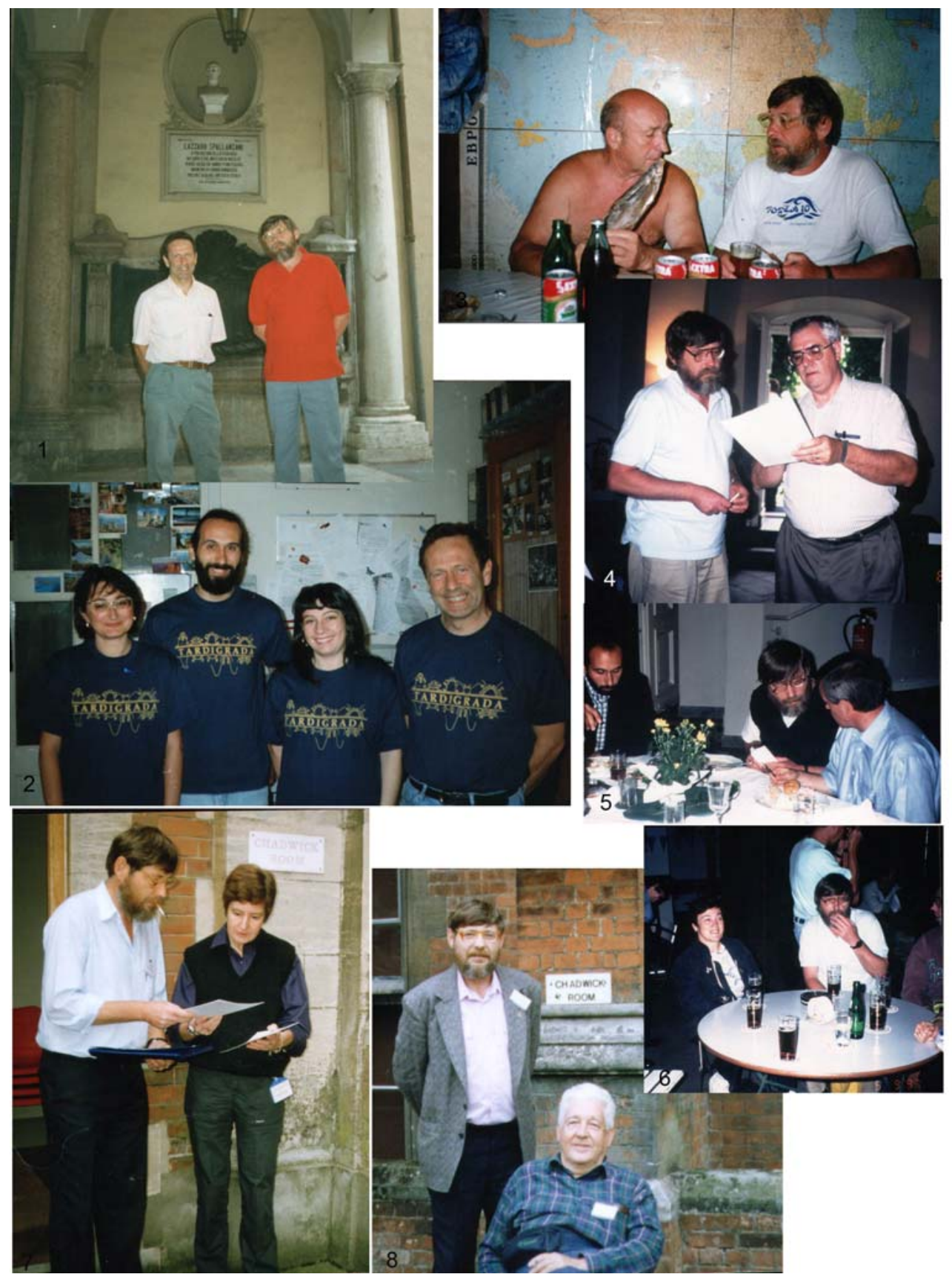

1. Prof. R. Bertolani (to the left) and V. Biserov with Lazzaro Spallanzani bust in the University of Modena. 1. Профессор Роберто Бертолани и Владимир Бисеров вместе с «отцом-основателем» Спаланцани в Моденском университете.

2. Research group in the University of Modena: L. Rebecchi, R. Guidetti, A.Guidi, R. Bertolani.

2. Группа тардиградологов из университета Модены: Лорена Ребекки, Роберто Гуидетти, Алессандра Гуиди, Роберто Бертолани. 
Vladimir during his expedition to Novaya Zemlya islands, and subsequently sent to Biserov new unpublished novels, being interested in opinion of this thoughtful researcher. Тебе, дорогому товарищу, передаю мою работус глубочайшим почтением и симпатией ${ }^{1}$, is written on Vladimir's copy of the book by Walter Maucci, Phylum Tardigrada. Maucci was a close colleague of Romatsotti, the coryphaeus of tardigradology in the world. They met with Biserov in Italy and England, discussed the problems of zoogeographic distribution of tardigrades and taxonomy. They resembled each other with slow and unhurried behavior, which is, though, what distinguishes all slow walkers! Warm friendship and deep mutual respect, academic interests and close cooperation tied Vladimir with Roberto Bertolani, Professor of University of Modena, and his students and followers - Lorena Rebecchi and Roberto

${ }^{1}$ To you, dear friend, with the deepest respect and affection
Guidetti. In 1995, Professor Bertolani went to Borok to visit his Russian friend and work with his collection of Tardigrada, which was of more than three thousand slides by then.

This collection Biserov bequeathed to the Hamburg Museum, to his friend and colleague, museum curator Hieronymus Dastych. However, bureaucratic obstacles did not allow to execute his will precisely. The collection was deposited at the Natural History Museum of Verona instead, which already had tardigradology collections of G. Ramazzotti and W. Maucci. Now this comes out to be a good solution, depositing all major Tardigrada collections in one place.

39 new species, 3 new genera, collection of tardigrades of Russia and adjacent areas, about 40 publications and extensive research archive this legacy Vladimir Biserov left to the future zoologists.

Natalia M. Biserova, translation from Russian by Gleb V. Biserov

3. Informal communication during the collection and study of tardigrades in Crimea, 1994.

3. Неформальное общение в процессе исследования тихоходок Крыма, 1994 г.

4. Prof. Miller and Dr. Biserov, Dusseldorf, Germany, 1997, the $7^{\text {th }}$ International Symposium on Tardigrada.

4. Профессор Миллер и Владимир Бисеров, Дюссельдорф, Германия, 1997 г.

5. H. Dastych (on the right), V. Biserov and R. Guidetti; the $7^{\text {th }}$ International Symposium on Tardigrada, Dusseldorf, Germany, 1997.

5. Дастих (справа), Бисеров, Гуидетти, 7-й Международный симпозиум, Дюссельдорф, Германия, 1997 г.

6. Vladimir with Silvana Ferrari, Germany, 1997.

6. Владимир и Сильвана Феррари, Дюссельдорф, 1997 г.

7. Arctic and Antarctic tardigrades met in Cambridge; V. Biserov and Sandra McInness, 1994

7. Тихоходки Арктики (В. Бисеров) и Антарктики (Сандра МакИннес), 1994, Кембридж.

8. Biserov and Walter Mauccci, 1994. It is one of the last photo of Maucci, he soon died during an expedition to Australia.

8. Вальтер Маучии, 1994 г. Одна из последних фотографий, мэтр вскоре погиб во время экспедиции в Австралии. 